\title{
Comparison of sleds versus plankton nets for sampling fish larvae and eggs
}

\author{
C. P. Madenjian \& D. J. Jude \\ Great Lakes Research Division, University of Michigan, Ann Arbor, MI 48109, U.S.A.
}

Keywords: fish larvae, sampling devices, Great Lakes, gear efficiency

\begin{abstract}
Fish larvae and fish eggs were sampled from the inshore waters of eastern Lake Michigan from 1978 through 1980, using a benthic sled and a plankton net towed within $0.5 \mathrm{~m}$ of the lake bottom. Differences between estimates of ichthyoplankton abundance based on the benthic sled and those based on the plankton net towed near bottom were examined along with interactions between gear, bottom depth, and time of day. Time of day was determined to be an important factor in comparing these two gear, but data were inconclusive as to the effect of depth on gear differences. Abundance of fish eggs calculated using sled tow data was significantly higher than that for the plankton net. For nighttime collections, density of alewife Alosa pseudoharengus larvae sampled in the plankton net significantly exceeded that for the sled, whereas density of spottail shiner Notropis hudsonius larvae based on sled data was significantly higher than that based on the plankton net for day sampling. Overall, the plankton net appeared to be adequate for sampling abundance of alewife larvae, while the sled was preferred for sampling fish eggs, spottail shiner larvae, and the following less common, but apparently demersal larvae: trout-perch Percopsis omiscomaycus, johnny darter Etheostoma nigrum, ninespine stickleback Pungitius pungitius, and slimy sculpin Cottus cognatus.
\end{abstract}

\section{Introduction}

Plankton nets and benthic sleds are commonly used gear to collect fish larvae. Sampling with a sled enables capture of fish larvae on or just above lake bottom; this space is not effectively sampled with an ordinary plankton net. Sleds have been developed by several researchers to collect demersal fish larvae from shallow water areas (Calhoun, 1953; Dovel, 1964; Frolander \& Pratt, 1962; Quadri, 1960).

A sled was employed in a study by Grossnickle \& Morgan (1979) to estimate density of opposum shrimp Mysis relicta in Lake Michigan. By sampling at different times of the day with both sled and plankton net, these researchers were also able to delineate daily migration patterns of Mysis. Differences between proportions of the five instars of Mysis collected in the two gear were also examined.
Yocum \& Tesar (1980) developed a benthic sled to sample demersal and shallow-water fish larvae in southeastern Lake Michigan in the vicinity of the D. C. Cook Plant. The sled was developed mainly to capture spottail shiner Notropis hudsonius larvae. These larvae were thought to be abundant in the inshore waters of the lake but few were collected during 1973 when just plankton nets were employed. During 1974 both plankton net and sled were used to sample larvae and results showed a large increase in number of spottail shiner larvae collected between the 2 years. Sled catch was relatively high and most of the spottail shiner larvae were caught at night (Jude et al., 1979). However it was observed that whenever densities of these larvae estimated by sled tow data were high during nighttime sampling, so too were densities for coincident plankton net tows. Yocum \& Tesar (1980) 
reported greater densities of alewife Alosa pseudoharengus larvae in plankton net tows than in sled tows and substantially greater densities of fish eggs caught in the sled than in the plankton net; these observations were for one beach station in the Cook Plant study area for June through August 1974.

The data set for fisheries monitoring at the J. H. Campbell Plant, eastern Lake Michigan, provided a unique opportunity to compare sled and plankton net densities over a period of several years. An extensive fish larvae sampling program was conducted in the area of the Campbell Plant including both sled tows and plankton net tows performed at 14 to 15 locations during each diel period of sampling. The primary objective of this paper was to determine differences between density estimates of fish larvae and fish eggs collected near bottom (within $0.5 \mathrm{~m}$ of lake bottom) by plankton net and sled in the vicinity of the J. H. Campbell Plant, 1978 through 1980, taking into account the effects of time of day and bottom depth. Establishing these differences would reflect: 1) differences between the spaces sampled by each gear, and 2) behavior of ichthyoplankton. Detecting differences between length frequencies of larvae in the two gear was the second objective of the study.

Our gear comparison study will describe relative biases in abundance estimates based on either gear. Kjelson (1977) and Schwartz (1973) have pointed out the need for research in determining relative efficiencies between sampling gear. Kjelson (1977) maintained that relative efficiencies (along with absolute efficiencies) for various gear are vital information required for estimating fish abundance.

\section{Sampling methods}

Fish eggs and larvae were sampled with a $0.5-\mathrm{m}$ diameter, nylon plankton net of number 2 mesh (363- $\mu \mathrm{m}$ aperture); a flowmeter was fitted to the frame of the net. The benthic sled consisted of a plankton net (number 2 mesh, 0.5-m diameter) within an aluminum frame with a towing bridle and a flowmeter attached (Yocum \& Tesar, 1980). The frame was roughly a rectangular solid in outline and was $194 \mathrm{~cm}$ long, $63 \mathrm{~cm}$ wide, and $33 \mathrm{~cm}$ high. The lower edge of the net mouth was held, within the frame, about $5 \mathrm{~cm}$ above lake bottom to eliminate sand trapping. Fish larvae were arbitrarily defined as any fish less than $2.54 \mathrm{~cm}$ total length. Those fish with total length greater than $2.54 \mathrm{~cm}$ were considered fry.

Fish larvae and eggs were sampled at two transects, about $3 \mathrm{~km}$ apart. Duplicate plankton net tows were performed (nets towed by hand) at three beach $(1 \mathrm{~m})$ stations; two at the north transect (power plant transect) and one at the south transect (reference transect). Five-min sled tows were also performed at beach stations with a sled dragged along the bottom by boat. Plankton net and sled tows were also conducted at 1.5-, 3-, 6-, 9-, 12-, and 15-m stations along both transects; these were all 5-min tows performed by boat using a towing speed of 3 to $6 \mathrm{~km} \mathrm{~h}^{-1}$. For every sled tow performed a corresponding plankton net tow was also performed near bottom. The paired tows of sled and plankton net were usually conducted within a few minutes of each other at most shallow water stations (1.5- and 3-m stations) stations and within $3 \mathrm{~h}$ of each other at deeper stations and beach stations.

Samples were preserved with $10 \%$ formaldehyde solution and later were examined under binocular microscopes. Fish larvae were identified and counted; fish eggs were also counted but were not identified to species.

During each sampling period collections were made during both day and night. Two sampling periods per month were included for June, July, and August, while only one per month was scheduled for April, May, and September. Sled tows at the farther north beach station at the north transect were not performed prior to June 1979.

\section{Statistical methods}

Data from 1978 through 1980 were analyzed using the Wilcoxon signed ranks test applied to the data set of each year separately for fish eggs, alewife, spottail shiner, yellow perch Perca flavescens, and rainbow smelt Osmerus mordax larvae. This statistical technique is the nonparametric analogue of the t-test for paired observations (Conover, 1971). The sled tow density and corresponding plankton net tow (near bottom) density were considered pairs. To apply this procedure, beach tow duplicate observations for a beach station were averaged to yield one value to be paired with the sled tow for that station. All zero differences or ties 
between pairs of observations were ignored.

Differences in ichthyoplankton density between the sled and plankton net were investigated using analysis of variance (ANOVA) which allowed direct examination of interactions. The experimental designs were analyzed as completely crossed, factorial models with sampling period (first one in April and the last in September), area (or transect), bottom depth ( 1 to $15 \mathrm{~m}$ ), gear, and time of day (day or night) as design variables. Sampling periods in which the taxon of ichthyoplankton was uncommon were not included in the design. The response variable was either number of larvae (or eggs) per $1000 \mathrm{~m}^{3}$ or a $\log _{10}$ transform thereof.

For each experimental design there was one observation per cell. Thus the highest-order interaction term was used as the error term, as performed by Jude et al. (1975). A Tukey test for additivity was performed on the ANOVA data sets to investigate the assumption that the highest-order interaction was not significant (Scheffé, 1959); results showed that this interaction was insignificant in all cases. Thus, despite not having an estimate of within cell error based on more than one observation per cell, the ANOVA was still a useful tool. ANOVA enabled us to analyze the interactions, to determine the relative importance of gear compared with other factors in the designed, and to have a comparison with results of the Wilcoxon signed ranks test.

\section{Results}

Results from the Wilcoxon signed ranks test showed that significantly higher densities of fish eggs were sampled by benthic sled than by plankton net, particularly during the day in 1978 and 1979 (Table 1). For alewife larvae at night in both 1979 and 1980 , density based on plankton net samples was significantly higher than that based on sled tows. Significantly higher densities of spottail shiner larvae were observed during the day in the sled than in the plankton net for years 1978 through 1980.

Analysis of variance results supported those from the Wilcoxon signed ranks test. One of the most significant effects for all designs examined was the gear effect for fish eggs where the mean fish

Table. I. Summary of Wilcoxon signed ranks test results (attained significance levels) for fish larvae and fish eggs collected in Lake Michigan in the vicinity of the J. H. Campbell Plant, eastern Lake Michigan, 1978 through 1980 . The gear with the greater median density is indicated in parenthesis for tests for which a significant difference was detected $(S=$ sled, $P N=$ plankton net).

\begin{tabular}{|c|c|c|c|c|}
\hline & \multirow[b]{2}{*}{ Year } & \multicolumn{3}{|l|}{ Diel period } \\
\hline & & Day & Night & $\begin{array}{l}\text { Day and } \\
\text { night pooled }\end{array}$ \\
\hline Alewife & $\begin{array}{l}1978 \\
1979 \\
1980\end{array}$ & $\begin{array}{l}0.7315 \\
0.7876 \\
0.7616\end{array}$ & $\begin{array}{c}0.9045 \\
0.0006^{* *}(\mathrm{PN}) \\
<0.0001^{* *}(\mathrm{PN})\end{array}$ & $\begin{array}{l}0.8926 \\
0.0395^{*}(\mathrm{PN}) \\
0.0014^{* *}(\mathrm{PN})\end{array}$ \\
\hline Spottail shiner & $\begin{array}{l}1978 \\
1979 \\
1980\end{array}$ & $\begin{array}{c}0.0125^{*}(\mathrm{~S}) \\
0.0011^{* *}(\mathrm{~S}) \\
<0.0001^{* *}(\mathrm{~S})\end{array}$ & $\begin{array}{l}0.3740 \\
0.6311 \\
0.6015\end{array}$ & $\begin{array}{l}0.0177^{*}(\mathrm{~S}) \\
0.0531 \\
0.0007^{* *}(\mathrm{~S})\end{array}$ \\
\hline Rainbow smelt & $\begin{array}{l}1978 \\
1979 \\
1980\end{array}$ & $\begin{array}{l}0.7000 \\
0.9394 \\
0.5901\end{array}$ & $\begin{array}{l}0.5014 \\
0.2297 \\
0.3385\end{array}$ & $\begin{array}{l}0.8303 \\
0.3466 \\
0.6970\end{array}$ \\
\hline Yellow perch & $\begin{array}{l}1978 \\
1979 \\
1980\end{array}$ & $\begin{array}{l}0.9143 \\
0.8444 \\
0.0380^{*}(\mathrm{~S})\end{array}$ & $\begin{array}{l}0.0260^{*}(\mathrm{PN}) \\
0.6791 \\
0.0250^{*}(\mathrm{PN})\end{array}$ & $\begin{array}{l}0.1153 \\
0.5941 \\
0.9139\end{array}$ \\
\hline Fish eggs & $\begin{array}{l}1978 \\
1979 \\
1980\end{array}$ & $\begin{array}{r}0.0001^{* *}(\mathrm{~S}) \\
<0.0001^{* *}(\mathrm{~S}) \\
<0.0001^{* *}(\mathrm{~S})\end{array}$ & $\begin{array}{c}0.0841 \\
0.0490^{*}(\mathrm{~S}) \\
<0.0001^{* *}(\mathrm{~S})\end{array}$ & $\begin{array}{l}<0.0001^{* *}(\mathrm{~S}) \\
<0.0001^{* *}(\mathrm{~S}) \\
<0.0001^{* *}(\mathrm{~S})\end{array}$ \\
\hline
\end{tabular}

\footnotetext{
* Significant $(\mathrm{p}<0.05)$

** Highly significant $(\mathrm{p}<0.01)$.
} 
Table 2. Mean densities (number $/ 1000 \mathrm{~m}^{3}$ ) by gear type for ANOVA designs for fish larvae and fish eggs collected in Lake Michigan in the vicinity of the J. H. Campbell Plant, eastern Lake Michigan, 1980. $N=$ number of observations in the design.

\begin{tabular}{lrrr}
\hline & N & $\begin{array}{l}\text { Plankton } \\
\text { net }\end{array}$ & Sled \\
\hline Alewife & 280 & 1570 & 1113 \\
Spottail shiner & 280 & 962 & 1123 \\
Rainbow smelt & 168 & 35 & 28 \\
Yellow perch & 112 & 70 & 34 \\
Fish eggs & 280 & 500 & 37482 \\
\hline
\end{tabular}

egg density for the sled was significantly greater than that for the plankton net (Table 2, 3). Mean density estimated using sled data was roughly 100 times higher than that for plankton net data in the ANOVA design for 1980 (this was the case for data from the 2 previous years as well). The depth effect was also significant with the vast majority of fish eggs collected in the beach to $3-\mathrm{m}$ zone. The time $\times$ gear interaction was significant both in 1978 and 1979. The striking feature of this interaction was the high density of eggs collected during the day with the sled (Fig. 1). However in 1980 neither the time $\times$ gear interactions nor the time of day factor was significant, since the density of eggs sampled in the sled at night was relatively high compared to previous years.

For alewife larvae, gear was not a significant factor in 1979 , but the time $\times$ gear interaction was highly significant that year. At night the density estimated using plankton net tows was substantially higher than that using sled tows (Fig. 1). However in 1980 the gear effect was significant (higher plankton net density than sled density).

Table 3. Percentage of variance explained by main effects in ANOVA designs for alewife and spottail shiner larvae and fish eggs collected in Lake Michigan in the vicinity of J. H. Campbell Plant, eastern Lake Michigan, 1980. Number enclosed in parentheses is the degrees of freedom for the factor.

\begin{tabular}{lccc}
\hline Factor & $\begin{array}{l}\text { Alewife } \\
\text { larvae }\end{array}$ & $\begin{array}{l}\text { Spottail } \\
\text { shiner } \\
\text { larvae }\end{array}$ & $\begin{array}{l}\text { Fish } \\
\text { eggs }\end{array}$ \\
\hline Sampling period (4) & 60.8 & 16.0 & 7.0 \\
Time of day (1) & 0.4 & 3.6 & 0.2 \\
Area (1) & 0.2 & 0.4 & 1.0 \\
Depth (6) & 9.6 & 30.4 & 19.4 \\
Gear (1) & 2.1 & 1.7 & 24.3 \\
\hline
\end{tabular}

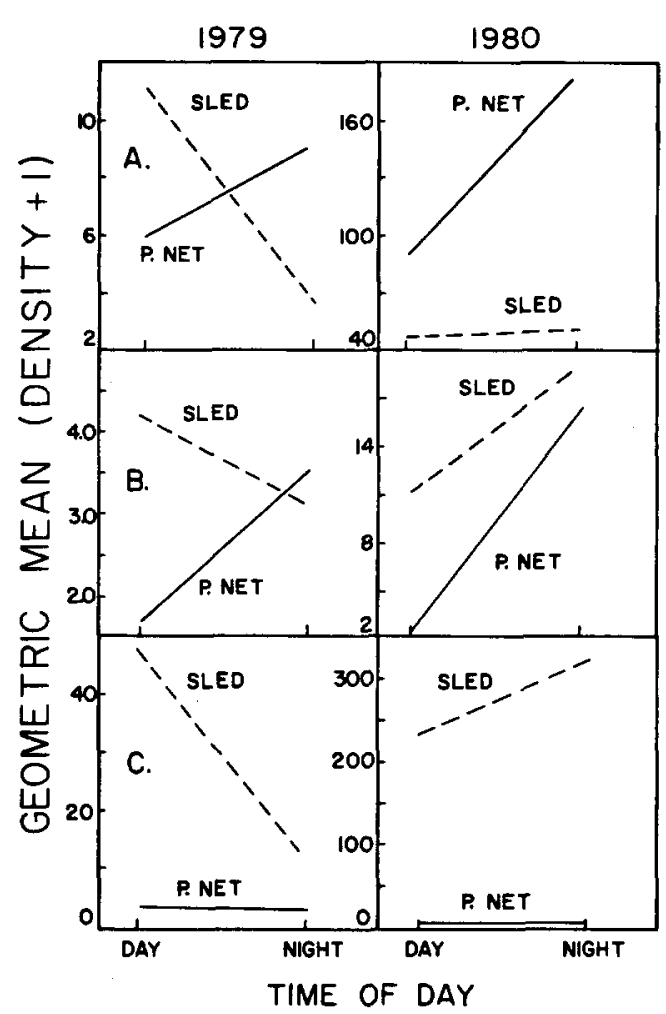

Fig. 1. Geometric mean density plus one of larval alewife (A), larval spottail shiner (B), and fish eggs (C) collected in plankton net and sled samples in Lake Michigan near the J. H. Campbell Plant, eastern Lake Michigan, 1979 and 1980. Graphs illustrate time $\times$ gear interactions. $P$. NET $=$ plankton net

Although the time $\times$ gear interaction for 1980 was not significant, it showed a substantially higher density based on plankton net data than based on sled data for the night (Fig. 1). For the 1980 ANOVA, the time $\times$ gear $\times$ depth interaction was significant, primarily due to the higher estimate of alewife larvae abundance based on sled samples than based on plankton net tows for the nearshore region ( 1 to $3 \mathrm{~m}$ ) during the day while the opposite was true for this same region at night. In deeper water (6 to $15 \mathrm{~m}$ ) during 1980 , density based on plankton net sampling was greater than that based on sled tows for both day and night.

As found for fish eggs and alewife larvae, depth was a highly significant factor for spottail shiner larvae with most of these larvae collected nearshore. Gear was not a significant main effect in 1979 , but the time $\times$ gear interaction was significant. In 1980 , as in 1978, gear was a significant 
factor (sled with higher mean density). Also for 1980 data, as for 1979 data, the time $\times$ gear interaction was significant with the prominent feature being the relatively low density recorded in plankton nets for day collections (Fig. 1).

For most sampling periods length frequencies of larvae for each gear type matched closely. There was a tendency for spottail shiner larvae length frequencies provided by sled data to exhibit a higher percentage of larger larvae than those provided by plankton net data for mid-July through early August sampling periods. This difference was not consistent throughout the years. There were a few cases where the higher percentage of larger spottail shiner larvae was collected in the plankton net rather than the sled. The most pronounced gear difference in length frequencies for spottail shiner larvae occurred in mid-July 1980 , when, on the average, larger larvae were caught in the sled (Fig. 2). There were a few cases where length frequencies of alewife larvae for each gear did not match. However within these cases of disparity, there were instances of a higher percentage of larger larvae captured by plankton net as well as those cases where the reverse was true with no trend in either direction. No disagreements between gear in length frequencies of yellow perch or rainbow smelt larvae were found. Densities and frequencies of collection of some less common species of larvae were too low to warrant formal statistical analysis.

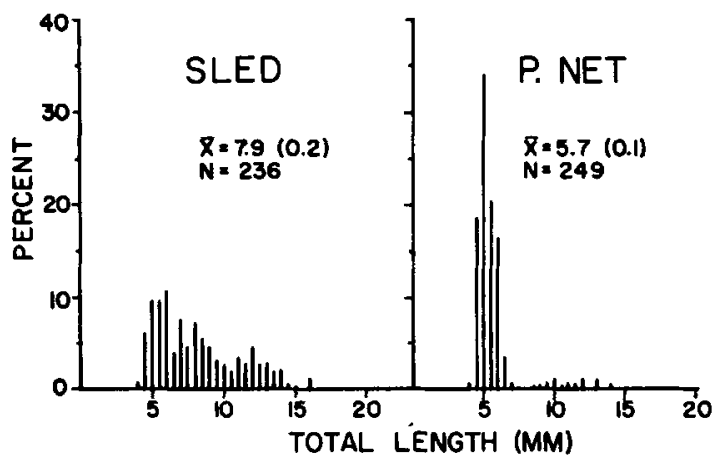

Fig. 2. Length-frequency histograms for spottail shiner larvae observed in south transect samples collected from beach, 1.5-, and 3-m stations during 14-16 July 1980 near the J. H. Campbell Plant, eastern Lake Michigan. Day and night data were pooled. $\overline{\mathrm{X}}=$ mean length, $\mathrm{N}=$ total number of larvae observed, $\mathrm{P} . \mathrm{NET}=$ plankton net, and the standard error of the mean length is indicated in parenthesis.
Table 4. Uncommon species of fish larvae caught more often in sled tows than in plankton net tows in Lake Michigan in the vicinity of the J. H. Campbell Plant, eastern Lake Michigan. Catch is in number of fish larvae and is pooled for all 4 years, 1977-1980.

\begin{tabular}{llcl}
\hline Species & $\begin{array}{l}\text { Sled } \\
\text { catch }\end{array}$ & $\begin{array}{l}\text { Sled and } \\
\text { plankton } \\
\text { net catch } \\
\text { pooled }\end{array}$ & $\begin{array}{l}\text { \% sled } \\
\text { catch of } \\
\text { total catch }\end{array}$ \\
\hline Trout-perch & 37 & 44 & 84 \\
Johnny darter & 93 & 116 & 80 \\
Ninespine stickleback & 29 & 38 & 76 \\
Slimy sculpin & 31 & 47 & 66 \\
\hline
\end{tabular}

Some of these less common species were more frequently caught by sled rather than plankton net; these species included trout-perch Percopsis omiscomaycus, johnny darter Etheostoma nigrum, ninespine stickleback Pungitius pungitius, and slimy sculpin Cottus cognatus (Table 4).

\section{Discussion}

When water hardened, most fish eggs of Lake Michigan species are known to be heavier than fresh water. However the distribution of fish eggs in the inshore area would depend on a number of factors including currents, rates of water hardening, and predation on eggs. Our statistical analyses showed that fish eggs are concentrated on the lake bottom, particularly at depths between 1 and $3 \mathrm{~m}$. Most fish eggs collected were from alewives and spottail shiners (Jude et al., 1980). Alewives were reported to spawn in water 1.5 to $2 \mathrm{~m}$ deep at night and spottail shiners primarily spawn in shallow water (Scott \& Crossman, 1973). Our data support the above observations as most fish eggs were found from the beach to $3 \mathrm{~m}$. Reasons for the relatively high sled density of fish eggs collected during the day in 1978 and 1979 are not clear. A break in this pattern was noted in 1980 when high densities provided by sled data were observed both for day and night sampling.

Mean density of alewife larvae was higher for plankton new tows than sled tows at night during both 1979 and 1980. Apparently alewife larvae, including newly hatched ones, were moving off the lake bottom at night. Alewife larvae may be better able to avoid the sled than the plankton net at night 
although this seems highly unlikely. Reasons for no differences between gear in 1978 are not known.

Spottail shiner larvae density was consistently greater for the sled than for the plankton net during the day. These larvae probably avoided the plankton net more effectively than the sled or tended towards lake bottom during the day. Data for spottail shiner larvae for the Cook Plant, $90 \mathrm{~km}$ to the south, in 1974 showed patterns most similar to 1978 and 1980 data at the Campbell Plant (Jude et al., 1979).

Two general trends were observed for the common species of fish larvae (alewife, spottail shiner, rainbow smelt, and yellow perch) collected during 1980. First, during the day and nearshore, density based on sled sampling was higher than the corresponding density based on plankton net tows; this difference was pronounced in the case of spottail shiner larvae. Secondly, there was a higher density estimate, using plankton net data, for night rather than day sampling; this difference was accented in the nearshore area and was again pronounced for spottail shiner larvae. Apparently net avoidance is an important factor in interpreting data for plankton net samples collected during the day, especially in shallow water. It is also quite possible that most larvae (particularly spottail shiner larvae) may be too close to lake bottom to be effectively sampled by plankton nets in this shallow water ( 1 to $3 \mathrm{~m}$ ) during the day, while at night more larvae are off the lake bottom than during the day. The pattern of higher density estimated by sled tow data than plankton net data during the day in the nearshore region was not evident for alewife, rainbow smelt, or yellow perch in the 2 previous years of the study. Thus, there were indications that depth is an important factor in considering differences between the gear, but the data were not conclusive in this regard.

\section{Conclusions}

The benthic sled is recommended for collecting fish eggs in eastern Lake Michigan. Densities based on plankton net tows were underestimates of egg abundance in the inshore region. The plankton net proved adequate for sampling alewife larvae abundance. The sled is advised for sampling spottail shiner larvae in eastern Lake Michigan since, overall, the density estimate based on the sled was greater than that based on the plankton net. However the statement that spottail shiner larvae are highly demersal should be qualified, because at night these larvae do appear to enter the water column above lake bottom. A sled is recommended for collection of larvae considered demersal, including trout-perch, johnny darter, ninespine stickleback, and slimy sculpin.

\section{Acknowledgements}

We would like to thank the many members of the Great Lakes Research Division's Fishery Laboratory for their help in the collection and processing of samples. Linda Gardner typed the manuscript and tables for this paper, while Dennis Mounsey assisted with figure preparation. The field study was part of the monitoring scheme for the J. H. Campbell Plant supported by Consumers Power Company, Jackson, Michigan. Contribution No. 419 of the Great Lakes Research Division, University of Michigan.

\section{References}

Calhoun, A. J., 1953. Distribution of striped bass fry in relation to major water diversions. Cal. Fish Game 39: 279-299.

Conover, N. J., 1971. Practical Nonparametric Statistics. John Wiley \& Sons, N.Y., 462 pp.

Dovel, W. L., 1964. An approach to sampling esturarine macroplankton. Chesapeake Sci. 5: 77-90.

Frolander, H. F. \& I. Pratt, 1962. A bottom skimmer. Limnol. Oceanogr. 7: 104-106.

Grossnickle, N. E. \& M. D. Morgan, 1979. Density estimates of Mysis relicta in Lake Michigan. J. Fish. Res. Bd Can. 36: 694-698.

Jude, D. J., F. J. Tesar, J. A. Dorr III, T. J. Miller, P. J. Rago \& D. J. Stewart, 1975. Inshore Lake Michigan Fish Populations near the Donald C. Cook Nuclear Power Plant, 1973. Univ, Mich., Gt Lakes Res. Div. Spec. Rep. 52, 267 pp.

Jude, D. J., F. J. Tesar, J. C. Tomlinson, T. J. Miller, N. J. Thurber, G. G. Godun \& J. A. Dorr III, 1979. Inshore Lake Michigan fish populations near the D.C. Cook Nuclear Power Plant during preoperational years - 1973, 1974. Univ. Mich., Gt Lakes Res. Div. Spec. Rep. 71, 529 pp.

Jude, D. J., H. T. Tin, G. R. Heufelder, P. J. Schneeberger, C. P. Madenjian, T. L. Rutecki, P. J. Mansfield, N. A. Auer \& G. E. Noguchi, 1981. Adult, Juvenile and Larval Fish Populations in the Vicinity of the J. H. Campbell Plant, Eastern Lake Michigan, 1977-1980. Univ. Mich., Gt Lakes Res. Div. Spec. Rep. 86, 367 pp. 
Kjelson, M. A., 1977. Estimating the size of juvenile fish populations in southeastern coastal-plain estuaries. In W. van Winkle (ed.), Proc. Conf. Assessing Effects of Power-PlantInduced Mortality on Fish Populs. Pergamon Press, N.Y.: $71-90$.

Quadri, S. U., 1960. A small drag net for capture of bottom fish and invertebrates. Prog. Fish Cult. 22: 90-91.

Scheffé, H., 1959. The Analysis of Variance. John Wiley \& Sons, N.Y., 477 pp.

Schwartz, F. J., 1973. An assessment of egg, larval, and juvenile fish research needs and problems, with comments on research at the University of North Carolina Institute of Marine Sciences. In A. L. Pacheco (ed.), Proc. Wkshop on Egg, Larval and Juvenile Stages of Fish in Atlantic Coast Estuaries. Middle Atlantic Cstl. Fish. Cent., Highlands, N.J., Tech. Publ. 1: 7-11.

Scott, W. B. \& E. J. Crossman, 1973. Freshwater fishes of Canada. Fish. Res. Bd Can. Bull. 184, 966 pp

Yocum, W. L. \& F. J. Tesar, 1980. Sled for sampling benthic fish larvae. Prog. Fish Cult. 42: 118-119. 